\title{
NOTES
}

\section{ATTEMPTS TO SECURE STATE LEGISLATIVE RESTRAINTS OF COMPETITION AS A VIOLATION OF THE ANTITRUST LAWS}

The typical antitrust suit involves a course of conduct consisting entirely of actions of private individuals or business entities. The issues to be litigated are the existence and significance of that conduct. ${ }^{1}$ In a few instances, however, antitrust suits have been instituted in which the alleged illegal conduct involved the instigation of judicial, ${ }^{2}$ administrative, ${ }^{3}$ or legislative ${ }^{4}$ action. Almost invariably these suits are challenged on the ground that private responsibility cannot be founded on the consequences of official acts. In cases involving action by state legislative bodies, this proposition has been accepted by some courts, ${ }^{5}$ while others regarded the nature of the acts constituting the course of conduct as irrelevant. ${ }^{6}$ Behind this divergence lies a basic problem not considered by the courts: the extent to which inducement of legislative activity for the purpose of effectuating a restraint of interstate commerce leads to a conflict between two important functions of government.

The first of these functions of government is to reconcile group interests,

1. "It is not of importance whether the means used to accomplish the unlawful objective are in themselves lawful or unlawful." American Tobacco Co. v. United States, 328 U.S. 781, 809 (1946).

2. See, e.g., Kobe, Inc. v. Dempsey Pump Co., 198 F.2d 416 (10th Cir.), cert. denied, 344 U.S. 837 (1952); United States v. Krasnov, 143 F. Supp. 184 (E.D. Pa. 1956).

3. See, e.g., Okefenokee Rural Elec. Membership Corp. v. Florida Power and Light Co., 214 F.2d 413 (5th Cir. 1954); Slick Airways, Inc. v. American Airlines, Inc., 107 F. Supp. 199 (D.N.J. 1952), appeal dismissed, 204 F.2d 230 (3d Cir.), cert. derned, 346 U.S. 806 (1953), 15 F.R.D. 175 (D.N.J. 1954); United States v. Association of Am. Railroads, 4 F.R.D. 510 (D. Neb. 1945).

4. See, e.g., Okefenokee Rural Elec. Membership Corp. v. Florida Power and Light Co., 214 F.2d 413 (5th Cir. 1954); Noerr Motor Freight, Inc. v. Eastern Railroad Presidents Conference, 113 F. Supp. 737 (E.D. Pa. 1953) ; United States v. Association of Am. Railroads, 4 F.R.D. 510 (D. Neb. 1945); Carolene Products Co. v. Evaporated Milk Ass'n, In Equity No. 15573 (N.D. Ill. 1937), aff'd, 93 F.2d 202 (7th Cir. 1938) ; Mills Novelty Co. v. National Dairy Products Corp., At Law No. 44394 (N.D. Iil.), aff'd per curiam sub nom. Mills Novelty Co. v. International Ass'n of Ice Cream Manufacturers, 87 F.2d 1012 (7th Cir. 1936). Cf. United States v. Sisal Sales Corp., 274 U.S. 268 (1927); American Banana Co. v. United Fruit Co., 213 U.S. 347 (1909) (cases in which action was sought from a foreign government).

5. Okefenokee Rural Elec. Membership Corp. v. Florida Power and Light Co. supra note 4; Carolene Products Co. v. Evaporated Milk Ass'n, supra note 4; Mills Novelty Co. v. National Dairy Products Corp., supra note 4. Cf. American Banana Co. v. United Fruit Co., supra note 4.

6. Noerr Motor Freight, Inc. v. Eastern Railroad Presidents Conference, $113 \mathrm{~F}$. Supp. 737 (E.D. Pa. 1953); United States v. Association of Am. Railroads, 4 F.R.D. 510 (D. Neb. 1945). Cf. Únited States v. Sisal Sales Corp., 274 U.S. 268 (1927). 
"to devise policies that provide an accommodation among conflicting drives, to maintain social unity despite the inevitable diversity of interest of social groups and classes. Freedom of association and freedom of expression of interest facilitate the resolution of conflict through open discussion of divisive issues. . . . T The chief vehicles for the expression of group interest are political parties and pressure groups. . . . ${ }^{8}$ Pressure groups fill a gap in our formal political system by performing a function of representation beyond the capacities of representatives chosen by the voters in geographical districts. . . . [T] heir representations to legislators constitute simply the normal process of governance in a regime which proceeds through consultation with those to be affected by legislation."

The second is regulation of individual and group conduct for the general welfare. The antitrust laws are an instance of such regulation in the economic sphere. They embody a judgment that the greatest social benefit is to be derived from a competitive economy; ${ }^{10}$ their scope indicates an intent to reach all instances of conduct inimical to that policy which Congress may constitutionally regulate. ${ }^{11}$ These functions of government conflict when individuals attempt to restrain competition by stimulating an exercise of governmental power, in that the democratic process is used to produce a result which Congress has declared undesirable. Therefore, the applicability of antitrust sanctions to such conduct cannot be considered apart from the basic governmental processes involved.

\section{The Scope of the Antitrust Laws in the Context of Private Action To Induce Legislative Restraints of Trade}

Where legislation affecting interstate commerce is sought from Congress, it seems clear that private action to bring it about must be outside the scope of the antitrust laws regardless of the motive for which it is sought. These laws are themselves acts of Congress and if the governmental process is to be responsive to the will of the people, individuals and interest groups cannot be denied the right to urge legislation which would modify or even repeal them. ${ }^{12}$ The Miller-Tydings and McGuire Acts, ${ }^{13}$ which modified antitrust policy in the area of resale price maintenance,

7. Key, Politics, Parties, and Pressure Groups 174 (3d ed. 1952).

8. KEY, op. cit. supro note 7 , at 24 .

9. KEY, op. cit. supra note 7, at 152 .

10. United States v. South-Eastern Underwriters Ass'n, 322 U.S. 533, 559 (1944); Apex Hosiery Co. v. Leader, 310 U.S. 469, 493 (1940).

11. United States v. South-Eastern Underwriters Ass'n, supra note 10, at 558.

12. Cf. American Banana Co. v. United Fruit Co., 213 U.S. 347, 358 (1909). "The fundamental reason why persuading a sovereign power to do this or that cannot be a tort ... is that it is a contradiction in terms to say that within its jurisdiction it is unlawful to persuade a sovereign power to bring about a result that it declares by its conduct to be desirable and proper."

13. Miller-Tydings Act, 50 STAT. 693 (1937), 15 U.S.C. $\$ 1$ (1952), amending 26 STAT. 209 (1890); McGuire Act, 66 STAT. 632, 15 U.S.C. \& 45 (a) (2) (1952), amending 38 STAT. 719 (1914). 
were largely the result of activity by private interest groups seeking an end which the antitrust laws prohibited. ${ }^{14}$

A solution to the problem of inducement of state legislative restraints of interstate commerce is less clear. A state may not regulate interstate commerce directly since this power is reserved to Congress under the Constitution. ${ }^{15}$ However, in the exercise of its police power to legislate for the health, safety, morals and welfare of its people, a state may enact legislation affecting interstate commerce ${ }^{16}$ if the legislation does not "impede substantially the free flow of commerce from state to state." 17 Without constitutional tolerance of this indirect power over interstate commerce, the police power would be substantially nullified. ${ }^{18}$ Thus, an exercise of the police power is proper if it has, as at least one of its objectives, a constitutionally proper subject of such legislation is sanctioned. In Stephenson v. Binford, ${ }^{19}$ plaintiff challenged a state statute which regulated use of the highways by trucks by effecting a redistribution of freight business between trucks and the railroads. The Court stated:

"We need not consider whether the act in some other aspect would be good or bad. It is enough to support its validity that, plainly, one of its aims is to conserve the highways. If the Legislature had other or additional purposes, which, considered apart, it had no constitutional power to make effective, that would not have the result of making the act invalid." 20

In Foster-Fountain Packing Co. v. Haydel, ${ }^{21}$ on the other hand, the Court granted a temporary injunction restraining the enforcement of a Louisiana conservation law which prohibited interstate shipment of unprocessed shrimp or their raw shells and heads upon a showing by plaintiffs that conservation was not the true purpose of the law.

"[T] he conservation of hulls and heads is a feigned and not the real purpose. . . . [T] he purpose of the enactment is to prevent the interstate movement of raw shrimp from the Louisiana Marshes ... [in order] to bring about the removal of the packing and canning industries from Mississippi to Louisiana. The conditions imposed by the Act upon the interstate movement of the meat and other products of shrimp are not intended, and do not operate, to conserve them for the use of the people of the State." 22

14. Key, op. cit. supra note 7 , at 96; Trunan, The Governmental Process 80 (1951).

15. Gibbons v. Ogden, 22 U.S. (9 Wheat.) 1, 197 (1824).

16. Southern Pac. Co. v. Arizona, 325 U.S. 761, 766-67 (1945) and cases cited.

17. Southern Pac. Co. v. Arizona, supra note 16, at 767.

18. South Carolina State Highway Dep't v. Barnwell Bros., Inc., 303 U.S. 177, 189 (1938).

19. 287 U.S. 251 (1932).

20. 287 U.S. at 276.

21. 278 U.S. 1 (1928).

22. 278 U.S. at 10. 
Here an exercise of the police power was invalidated because of the improper objective motivating it. Normally, however, if police power legislation lies within a traditional area it will withstand challenge on the ground of conflict with the commerce clause. Since Fletcher $v$. Peck $^{23}$ the courts have adhered to the doctrine, based on a theory of separation of powers, ${ }^{24}$ that the judiciary cannot inquire into the motives of the legislature in passing on the constitutionality of its enactments "except as [those motives] may be disclosed on the face of the acts, or inferrible from their operation." 25 Because of the privilege accorded legislative bodies against direct inquiry into their motives, a restraint of interstate commerce in a police power area may be upheld when in reality the legislative intent was solely to affect interstate commerce. ${ }^{26}$ This fact, and the fact that much police power legislation enacted to accomplish a proper objective may also affect interstate commerce, make lobbying for state legislation a potential means for effectuating a restraint on trade.

It is clear that governmental action imposing restraints upon interstate commerce is not within the purview of sections 1 or 2 of the Sherman Act. ${ }^{27}$ That the legislative intent in the Sherman Act was to prevent private not governmental, actions in restraint of competition ${ }^{28}$ was recognized by the Supreme Court in Olsen v. Smith. ${ }^{29}$ Plaintiffs, licensed under a Texas statute prohibiting persons from acting as pilots unless authorized by law, sued defendant unlicensed pilots for damages. In rejecting defendants' contention that the statute violated the Sherman Act, the Court said:

"The contention that because the commissioned pilots have a monopoly of the business, and by combination among themselves exclude all others from rendering pilotage services, is also but a denial of the authority of the State to regulate, since if the State has the power to regulate, and in so doing to appoint and commission, those who are to perform pilotage services, it must follow that no monopoly or combination in a legal sense can arise from the fact that the duly

23. 10 U.S. (6 Cranch) 87 (1810).

24. McCray v. United States, 195 U.S. 27, 53-59 (1904).

25. Soon Hing v. Crowley, 113 U.S. 703, 710 (1885). See also Daniel v. Family Security Life Ins. Co., 336 U.S. 220, 224 (1949); Arizona v. California, 283 U.S. 423, 455 n.7 (1931) ; cf. Sunbury \& Erie R.R. v. Cooper, $33 \mathrm{~Pa} .278$ (1859). (1902).

26. Cf. Florida Central \& Peninsular R.R. v. Reynolds, 183 U.S. 471, 480

27. Section 1 of the Sherman Act proscribes "every contract, combination . .; or conspiracy, in restraint of trade or commerce among the several States. ..." Section 2 makes illegal monopolization or attempts to monopolize "any part of the trade or commerce among the several States. . . "26 STAT. 209 (1890), as amended, 15 U.S.C. $\$ \$ 1,2$ (1952). Section 2 supplements $\$ 1$ so that "by no possible guise [can] the public policy embodied in the first section be frustrated or evaded." Standard Oil Co. v. United States, 221 U.S. 1, 60 (1911). By its terms, violation of $\S 1$ can occur only where two or more individuals act in concert. Where individual activity is referred to in this Note in connection with a $\$ 1$ violation, this prerequisite is understood to have been met.

28. For a brief review of the legislative history, showing that prevention of privately-imposed restraints of competition was the problem considered, see Apex Hosiery Co. v. Leader, 310 U.S. 469, 493 n.15 (1940).

29. 195 U.S. 332 (1904). 
authorized agents of the State are alone allowed to perform the duties devolving upon them by law." 30

Although governmental action itself may be immune from the antitrust laws, logic does not compel the conclusion, where a state legislature is involved, that private inducement of that action need also share the immunity. ${ }^{31}$ The susceptibility of state lobbying activity, to sections 1 and 2 of the Sherman Act depends, instead, on the intended scope of those sections on the one hand, and on limitations on congressional power on the other. A number of the cases have recognized this distinction between the validity of state legislation affecting interstate commerce via the police power, and private activity directed toward the enactment of state legislation for the purpose of restraining competition..$^{32}$ However, the opinions are phrased in terms of a general proposition that "lawful means may not be used to achieve an unlawful end," which is, in terms of the problem, an oversimplification.

Legislative history does not indicate whether Congress specifically considered private action to secure governmental restraints of competition, as distinguished from the governmental action itself, to be outside the scope of sections 1 and 2 of the Sherman Act. There is evidence, however, that in enacting the Sherman Act, Congress intended to reach all subjects and species of conduct within the breadth of its regulatory power under the commerce clause. ${ }^{33}$ The broad language of sections 1 and 2 can comprehend any private conduct whose purpose or effect is to restrain interstate commerce unless that conduct is protected by a constitutional limitation on congressional power or unless Congress itself has created an exemption. ${ }^{34}$ The only important doctrinal qualification to this proscription is the judicially enunciated "rule of reason," which holds that only those restraints of trade which are unreasonable are illegal. ${ }^{35}$ Though this doctrine may shield certain instances of lobbying activity from antitrust sanctions it by no means immunizes all. $^{36}$

30. 195 U.S. at 344-45. See also Parker v. Brown, 317 U.S. 341, 351 (1943) and cases cited.

31. An individual may be prosecuted under the Sherman Act even though his improper conduct has been effectuated through an innocent third party. United States v. Patten, 226 U.S. 525, 541 (1913) ; Johnson v. J.H. Yost Lumber Co., 117 F.2d 53, 61 (8th Cir. 1941).

32. See cases cited note 6 supra.

33. See note 11 supra.

34. Examples of such exemptions are those for export associations, state resale price maintenance schemes, labor activities and agricultural cooperatives. For a brief

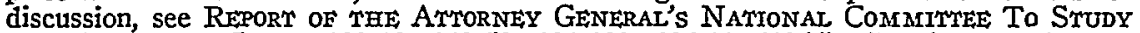
THE, ANTITRUST LAws 109-10, 149-53, 294-300, 306-11 (1955) (hereinafter cited as REPORT).

35. See Report at 5, 11.

36. The rule of reason requires a court to examine allegedly illegal conduct in its economic context, including its purpose, operation and effect, so as to determine whether the restraint is unreasonable under the circumstances. The doctrine is not a bar to application of $\S \S 1,2$ of the Sherman Act to lobbying activity so long as the reasonability of the restraint vis a vis the competitive position of the parties affected is distinguished from the reasonability of the restraint from the legislative standpoint. 
Application of sections 1 and 2 of the Sherman Act does not depend upon the motive of the lobbyist in inducing legislative activity. Although it is easier analytically to envisage a Sherman Act violation in terms of a party whose motive is to weaken his rival's competitive position, a party who urges legislation for reasons consistent with proper police power objectives may be in no better position. If one of the foreseeable effects of the enactment is the enhancement of his own competitive position at the expense of his rival, he would seem to be equally within the Sherman Act ban. ${ }^{37}$

\section{Constitutional Limitations on Congressional Power}

In determining the permissible scope of Sherman Act enforcement in the area of private activity to induce legislative restraints of trade, certain constitutional limitations on congressional power must be recognized. The first is the nature of the federal system, which gives authority to the states over matters concerning the health, safety, morals and welfare of their people. The second is the first amendment of the Constitution, which guarantees freedom of speech and the right to petition the Government for a redress of grievances.

\section{Limitation Imposed by the Nature of the Federal System}

All powers not delegated to the national government are reserved to the states under our federal system of government. The operation of this system presumes that each level of government will interfere as little as possible in the legitimate sphere of operations of the other. However, there is an inevitable coincidence of authority in some areas. A state "police power" enactment, for example, may impinge upon interstate commerce. Since such coincidence of authority is part of the federal system, it would seem necessary, in the context of the present problem, to so interpret congressional power and thus the Sherman Act that it does not unduly encroach upon the state legislative process. A necessary element of this process is communication between the state legislature and the citizens of the state. When a citizen who is motivated by an objective properly the concern of the state urges police power legislation, his conduct must be regarded as an integral part of the operation of the federal system and therefore entitled to exemption from the antitrust laws. If, however, an individual seeks an exercise of the police power for the purpose of undermining a competitor's position, he is no longer concerned with a proper

If the enactment is in a traditional police power area and if the legislature could have had a proper objective in enacting it, the concomitant restraint may, from a legislative standpoint, be valid, i.e., not subject to challenge on constitutional grounds and therefore "reasonable." Viewed, however, as the product of activity by a private party seeking to affect adversely the competitive position of another, the same restraint may be unreasonable within the standards developed under the doctrine and may justify the imposition of antitrust sanctions.

37. Good motive is not a defense to a prosecution for acts in violation of the antitrust laws. Standard Sanitary Mfg. Co. v. United States, 226 U.S. 20, 49 (1912); American Amusement Co. v. Ludwig, 82 F. Supp. 265, 267 (D. Minn. 1949). 
function of the state legislative process. Accordingly, the federal principle does not demand the same protection from antitrust sanctions. Such a distinction on the basis of motive also accords with the relative danger to federal competitive policy in each of the two cases. Moreover, since the reasons which preclude judicial investigation of the motives of a legislature do not apply to an investigation of the motives of those who urge legislation, ${ }^{38}$ federal antitrust law could reach conduct directed toward ends prohibited by it even though the validity of any state legislation that might result from such conduct may not be challenged.

\section{Privilege Under the First Amendment Guarantees of Freedom of Speech and Petition}

While principles of federalism may not preclude the application of antitrust sanctions to private action consciously seeking a restraint of competition through the enactment of state laws, the constitutional protection which the first amendment accords to the process of invoking legislation may do so. Rights protected by the first amendment are the basis of our political democracy. ${ }^{39}$ As Justice Brandeis stated, concurring in Whitney v. California: ${ }^{40}$

"Those who won our independence . . . believed that freedom to think as you will and to speak as you think are means indispensable to the discovery and spread of political truth; that without free speech and assembly discussion would be futile; that with them, discussion affords ordinarily adequate protection against dissemination of noxious doctrine; that the greatest menace to freedom is an inert people; that public discussion is a political duty; and that this should be a fundamental principle of the American government." 41

These rights are not absolute, but their great importance requires that they be restricted only where necessary "to protect the State from destruction or from serious injury, political, economic or moral." 42 If the antitrust laws are applicable to private action by individuals or groups ${ }^{43}$ urging the enactment of state legislation, a serious restraint is placed on the exercise of the first amendment freedoms of speech and petition. It is necessary, then, to inquire into the principles determining when first amendment rights

38. Compare the lobbying acts of many states and the federal government, which require professional lobbyists to register and file reports in order that the legislature may better evaluate the propaganda directed toward it. See KEY, op. cit. supra note 7, at 158-59; Comment, Improving the Legislative Process: Federal Regulation of Lobbying, 56 YaLE L.J. 304, 327-28 (1947).

39. See, e.g., Harisiades v. Shaughnessy, 342 U.S. 580, 592 (1952); De Jonge v. Oregon, 299 Ü.S. 353, 365 (1937) ; United States v. Cruikshank, 92 U.S. 542, 551$52(1875)$.

40. 274 U.S. 357 (1927).

41. 274 U.S. at 375.

42. Id. at 373. See also United Pub. Workers, CIO v. Mitchell, 330 U.S. 75, 95 (1947) and cases cited n.30.

43. United States v. CIO, 335 U.S. 106, 143-44 (1948). 
may be restricted. Due to limited case law on the right of petition, these principles will be developed through analysis of the cases involving freedom of speech and press. ${ }^{44}$

Decisions dealing with the right of government to restrict or prohibit freedom of speech and press are of two basic types: those in which there is direct restriction of the exercise of the right and those in which there is indirect restriction through regulation of particular conduct, deemed inimical to the public welfare, with which the exercise of the right is associated. ${ }^{45}$ While the problem of restriction is the same in both types of cases, the difference in the situation which gives rise to it has led the Supreme Court to a different approach in each.

Direct restrictions on these freedoms have been relatively limited in nature. Chafee ${ }^{46}$ has classified them as protection of individuals against falsehood (e.g., libel, slander); protection of common standards of the community (e.g., moral and religious standards by laws against obscenity and blasphemy; social and political standards by teachers' oaths, antievolution laws, compulsory flag salutes) ; security against internal violence (e.g., sedition, contempt of court) ; and security against external aggression (e.g., treason, interference with a war effort). These restrictions, particularly those intended to prevent internal violence and external agression, formed the context in which the "clear and present danger" test 47 was developed. Viewed merely as a formula, such a test is of limited usefulness since it does not explain the constitutionality of restrictions of expression outside the political and economic sphere. ${ }^{48}$ Viewed as an attempt to evaluate the essential considerations in judging restraints of speech and press, the requirement of "clear and present danger" becomes more meaningful. It seeks to protect the social value of free expression by permitting its restriction only when there is strong evidence that the individual's words will result in an immediate substantial evil. ${ }^{49}$ Basically, the test requires determination of the seriousness of a threat to society, as measured by its substantive nature and the probability of its occurrence, that will justify a direct infringement of a constitutionally protected liberty. These considerations are also the basis of decisions involving attempts to protect in-

44. On the problem of limitation of the first amendment rights of free speech and press see generally, Mendelson, Clear and Present Danger-From Schenck to Dennis, 52 Colum. L. REv. 313 (1952); Comment, Current Limitations on Governmental Invasion of First Amendment Freedoms, 13 Oн1о Sr. L.J. 237 (1952).

45. Dennis v. United States, 341 U.S. 494, 502-11 (1951); American Communications Ass'n v. Douds, 339 U.S. 382, 393-400 (1950).

46. 1 ChafEe, Government and Mass Communications 61, 77-468 (1947).

47. The test was first employed by Justice Holmes in Schenck $v$. United States: "The question in every case is whether the words are used in such circumstances and are of such a nature as to create a clear and present danger that they will bring about the substantive evils that Congress has a right to prevent." 249 U.S. 47, 52 (1919). The early cases employing this test are cited in American Communications Ass'n v. Douds, 339 U.S. 382, 395 n.9 (1950).

48. 1 Chafee, op. cit. supra note 46 , at $52-53,58$.

49. American Communications Ass'n v. Douds, 339 U.S. 382, 395, 397 (1950). 
dividuals against falsehood ${ }^{50}$ and attempts to protect community standards, ${ }^{51}$ though these cases do not employ the clear and present danger test. ${ }^{52}$

Cases involving restrictions on expression because of an attempt to regulate other conduct cover a much broader range of activity. Again the Court has had to decide how great a threat to society will be required to justify a restriction of first amendment freedoms. But here, the threat is not from the exercise of the right itself but from other conduct accompanying its exercise. Thus, it is the injury threatened by the conduct that is balanced against the first amendment right in determining whether its exercise may constitutionally be restricted. ${ }^{53}$ In performing this task, the Court has developed certain standards. When examining the evil, prevention of which is the alleged justification of the restriction, it has looked first to see that the legislation is not in fact aimed at the suppression of unpopular ideas or is so broad or vague as to cover activities which are clearly protected by the first amendment. ${ }^{54}$ A legitimate purpose being found, the Court has looked to its substantive importance, as measured by the nature of the harm sought to be prevented ${ }^{55}$ and the probability of its occurrence, ${ }^{56}$ to determine the magnitude of the threat to society posed by the conduct. Against this is balanced the extent to which the constitutionally protected right is infringed. ${ }^{57}$ The operation of this process has been summarized by the Court as follows:

'In each case [courts] must ask whether the gravity of the 'evil,' discounted by its improbability, justifies such invasion of free speech as is necessary to avoid the danger. [This test] takes into consideration those factors which we deem relevant, and relates their significance." 58

Although there are two distinct situations in which the problem of restriction of first amendment rights arises, the principles which the Court

50. Compare Beauharnais v. People, 343 U.S. 250, 256-57 (1952) and cases cited, with Near v. Minnesota, 283 U.S. 697, 713-19, 722 (1931).

51. See, e.g., Joseph Burstyn, Inc. v. Wilson, 343 U.S. 495, 504-05 (1952).

52. 1 CEAFEE, op. cit. supra note 46 , at 54-58. The formulation of this test in terms of the chronological proximity of the threatened evil makes it inapplicable to those situations where the utterance of the words themselves constitutes the evil and to those where the evil does not bear a close temporal relationship to the speech causing it (e.g., destruction of moral standards).

53. American Communications Ass'n v. Douds, 339 U.S. 382, 398-400 (1950) and cases cited.

54. See, e.g., Thomas v. Collins, 323 U.S. 516, 547 (1945) (concurring opinion); Martin v. City of Struthers, 319 U.S. 141, 147 (1943); De Jonge v. Oregon, 299 U.S. 353, 365 (1937).

55. For cases in which the interest sought to be protected was held to be too insubstantial see, e.g., Niemotko v. Maryland, 340 U.S. 268, 276 (1951); Marsh v. Alabama, 326 U.S. 501 (1946); Schneider v. State, 308 U.S. 147 (1939).

56. See, e.g., Terminiello v. Chicago, 337 U.S. 1, 6 (1949); Giboney v. Empire Storage Co., 336 U.S. 490, 503 (1949).

57. See, e.g., United Pub. Workers, CIO v. Mitchell, 330 U.S. 75, 99 (1947); Thornhill v. Alabama, 310 U.S. 88, 104 (1940).

58. Dennis v. United States, 341 U.S. 494, 510 (1951). 
has followed in each suggest a common rationale. The fundamental importance of freedom of speech and press to the democratic process requires that the exercise of these rights be restricted only where it threatens a substantial injury which the democratic process cannot prevent by its own workings. Where the injury is threatened as a consequence of speech itself, restraint is justified only when the speech of others cannot avert it. ${ }^{59}$ Where substantial injury is threatened as a consequence of conduct of which speech is only a part, speech alone may not be able to avert the injury and in this context restraint may be justified although such speech could not be restrained by itself. ${ }^{60}$

Regardless of the particular conduct involved, the first amendment presents a serious obstacle to the application of antitrust sanctions in the area of private efforts to obtain enactment of state legislation restraining competition. This obstacle seems greater, however, where the conduct has consisted solely of an exercise of the rights of petition and free speech than where it has also involved other acts directed toward the restraint of competition. To extend the antitrust laws to conduct of the first type, even though the rights of speech and petition were exercised pursuant to a conspiracy and from an improper motive, would constitute a direct restraint on their exercise. It is doubtful that conduct limited to the exercise of these rights threatens an injury to competition which the democratic process cannot prevent by its own workings. Those who are opposed to such legislation have an equal opportunity to exert their influence on the legislature and to enlist what support they can arouse among the rest of the electorate. It seems unlikely that legislation thus opposed would be enacted without substantial support from persons not motivated by a desire to restrain competition. Attaching civil and criminal penalties to the possible results of this process would appear to be an unconstitutional interference with first amendment rights.

Where there has been activity directed toward restraint of competition that involved more than the exercise of the first amendment freedoms, there may exist a course of conduct which could be restrained despite the concomitant restriction of the rights of speech and petition. This would most clearly be true when the other acts consisted of such direct attempts to restrain competition as, for example, price fixing. The democratic process cannot prevent restraints imposed in this manner and the social policy embodied in the antitrust laws is of sufficient importance to justify the infringement of first amendment rights exercised in conjunction with such activity. Speech is involved in every conspiracy, a fact that has never been thought to prevent criminal punishment. ${ }^{61}$ That the right of peti-

59. See, e.g., Whitney v. California, 274 U.S. 357, 377 (1927) (concurring opinion of Justice Brandeis); Gilbert v. Minnesota, 254 U.S. 325, 337-38 (1920) (dissenting opinion of Justice Brandeis).

60. Giboney v. Empire Storage Co., 336 U.S. 490, 498-503 (1949).

61. Id. at 502 . 
tion has also been used in furtherance of a general effort to restrain competition would not seem to alter this conclusion. ${ }^{62}$

Where the accompanying course of conduct has been an attempt to manipulate the legislative process, however, the right to treat such conduct as separate from the exercise of first amendment freedoms becomes less clear. The use of front organizations to circulate false and misleading information to the public and to government officials and the creation of apparently independent groups to give the illusion of additional support for the legislation sought are examples. ${ }^{\text {B3 }}$

Perhaps such activity can be analogized to the abuse of administrative or judicial processes, which has been recognized as a violation of the antitrust laws. ${ }^{64}$ In Kobe, Inc. $v$. Dempsey Pump Co., ${ }^{65}$ where defendant had brought a patent infringement suit against plaintiff for purposes of harassment, the court remarked:

"It is said that to allow recovery of damages resulting from the infringement action would be a denial of free access to the courts. . . . At the same time we must not permit the courts to be a vehicle for maintaining and carrying out an unlawful monopoly which has for its purpose the elimination and prevention of competition." 68

If there has been "abuse of the legislative process" it might reasonably be said that this is conduct designed to bring about a serious evil (restraint of competition) which others, by the exercise of their rights of speech and petition alone, may not be able to prevent. Since such conduct indicates that those engaging in it seek to impose their desires on others without regard for the democratic process and there is the possibility of serious social injury through deception of the legislature, civil and criminal liability would seem to be consistent with the first amendment. ${ }^{67}$

62. Cf. United States v. Sisal Sales Corp., 274 U.S. 268 (1927).

63. See, e.g., the allegations of the complaint in Noerr Motor Freight, Inc. v. Eastern Railroad Presidents Conference, 113 F. Supp. 737, 741 (E.D. Pa. 1953).

64. See cases cited notes 2 \& 3 supra. Contra, Okefenokee Rural Elec. Membership Corp. v. Florida Power and Light Co., 214 F.2d 413 (1954).

65. 198 F.2d 416 (10th Cir), cert. denied, 344 U.S. 837 (1952).

66. 198 F.2d at 424 .

67. It may be, however, that the more appropriate control for such abuses of the legislative process lies in legislation specifically designed to protect it, the lobbying acts. These acts, which exist in over half the states, require registration of lobbyists and, in general, the filing of financial reports. KEY, op. cit. supra note 7, at 158. Their primary objective is to assure publicity of lobbying activities, on the theory that this will enable the legislature to evaluate these pressures more accurately. KEY, op. cit. supra note 7, at 158 . For purposes of antitrust enforcement, it would seem that reliance on these acts, if they are effective, is preferable to the imposition of punitive sanctions under the antitrust laws themselves. An enlightened legislature is probably a greater safeguard against would-be antitrust violators who seek to "use" it than any threat of possible civil and criminal prosecutions; and, in addition, costly litigation is avoided. As lobbying legislation exists today, however, such reliance is unrealistic. A large number of states have no such acts and, of those that do, many require only "Iistless compliance." KEY, op. cit. stipra note 7, at 158. It seems doubtful that general legislative enlightenment can be presumed under such circumstances. Thus, although the imposition of antitrust penalties may be theoretically less effective, it has the advantage of more widespread and vigorous enforcement which, in practice, should 


\section{Evimentiary Problems in Private Actrons To Impose Antitrust Sanctions on Lobbying Activity Within the Scope of the ANtitrust Laws}

Certain special evidentiary problems affect the antitrust sanctions which may be invoked by private individuals when lobbying activities of others constitute the alleged violation. Section 7 of the Sherman Act as amended by section 4 of the Clayton Act ${ }^{68}$ grants a right of action for treble damages, attorney's fees and costs of suit to "any person who shall be injured in his business or property by reason of anything forbidden in the antitrust laws." Section 16 of the Clayton Act ${ }^{69}$ grants the right to injunctive relief "against threatened [conduct that will cause] loss or damage by a violation of the antitrust laws." To maintain the action for treble damages, it is necessary for the plaintiff to establish three things: that the defendant has violated the antitrust laws; that the acts constituting this violation have caused damage to him; and the amount of these damages. ${ }^{70}$

Assuming that defendant's ends in seeking state legislation constitute a violation of the antitrust laws, establishment of the causal connection between defendant's activity and the passage of the legislation poses unique difficulties because of the doctrine that courts may not inquire into motives of the legislature. This principle, which created difficulty on the constitutional plane in determining the extent to which private action to induce state legislative restraints of trade could be brought within the scope of the Sherman Act, again becomes important on a practical level when other individuals seek to impose the sanctions of the antitrust laws on such conduct. ${ }^{71}$

The decisions which establish the immunity from judicial inquiry of legislative motives were concerned either with attempts to invalidate legislation on the basis of the motives which lead to its passage ${ }^{72}$ or attempts to hold legislators personally liable for their conduct in the performance of their duties. ${ }^{73}$ Thus the interests sought to be protected by the rule would seem to be first, the general constitutional right of the legislative

make it the more effective remedy. Although control of lobbying activities is basically a matter of state concern, federally created sanctions may properly be imposed in the antitrust area, since this problem is one of national significance. If congressional policy is to be served, the control of private attempts to secure legislative restraints of trade appears to require the imposition of antitrust sanctions where appropriate. Any beneficial effects of lobbying legislation would be supplementary and in no way lessened.

68. 38 STAT. 731 (1914), 15 U.S.C. § 15 (1952).

69. 38 STAr. 737 (1914), 15 U.S.C. $\S 26$ (1952).

70. Greenleaf v. Brunswick-Balke-Collender Co., 79 F. Supp. 362, 364 (E.D. Pa. 1947). See also Turner Glass Corp. v. Hartford Empire Co., 173 F.2d 49, 51-52 (7th Cir. 1949); Suckow Borax Mines Consolidated, Inc. v. Borax Consolidated, Ltd., 81 F. Supp. 301, 305 (N.D. Cal. 1948).

71. The problem does not exist when relief is sought by the federal government since it is unnecessary for it to prove that defendant's activities succeeded in restraining competition. Only the attempt to do so need be shown.

72. See cases cited notes 24-26 supra.

73. See, e.g., Tenney v. Brandhove, 341 U.S. 367, 377-78 (1951). 
branch to operate freely within its sphere of power and, second, the freedom of individual legislators to perform their duties without fear of civil or criminal liability. The interest in protecting legislators in the discharge of their duties seems to require that they not be burdened by inquiries into their motives, even though the matter does not involve any personal liability. This would not preclude an attempt to prove by circumstantial evidence the factors that influenced their actions, nor would such an attempt violate the principle of separation of powers. However, it is questionable whether circumstantial evidence alone would be adequate.

The standard of proof for causation in treble damage suits, as stated in Bigelow v. RKO Radio Pictures, ${ }^{74}$ is that

". . . in the absence of more precise proof, the jury could conclude as a matter of just and reasonable inference from the proof of defendants' wrongful acts and their tendency to injure plaintiffs' business, and from the evidence of the decline in prices, profits and values, not shozen to be attributable to other causes, that defendants' wrongful acts had caused damage to the plaintiffs." (Emphasis added.) ${ }^{\mathbf{7 5}}$

Where the basis of the action is defendant's unlawful activity leading to the enactment of injurious state legislation, it would appear almost impossible to prove by circumstantial evidence that such legislation was not attributable to other causes. Equally difficult is the case where defendant's activity has been directed toward the defeat of a bill favorable to plaintiff's competitive position. A controversial bill produces many pressures on the legislature, a number of which may be influential in determining each legislator's vote. Even under the more liberal standard of causation suggested in Momand $v$. Universal Film Exchange, Inc., ${ }^{78}$ "a more substantial cause of loss than any other known cause," or the standard of general tort law, "a material element and a substantial factor" in bringing about the event, ${ }^{7 \pi}$ proof would be very difficult. Although it might be shown that defendant's conduct constituted the greatest single influence brought to bear on the legislature, there is always the possibility that it discounted this pressure and would have enacted the legislation, for other reasons, without it. ${ }^{78}$ Only where a bill favorable to plaintiff has been

\section{327 U.S. 251 (1946).}

75. Id. at 264.

76. 72 F. Supp. 469,480 (D. Mass. 1947).

77. PROSSER, TORTS $\& 44$ (2d ed. 1955).

78. If the plaintiff is able to prove that defendant's acts have been the cause of injury to him, the courts are liberal in admitting evidence to establish the amount of his damages. Where the amount cannot be fixed with certainty, damages may still be recovered on "probable and inferential, as well as direct and positive proof." Bigelow v. RKO Radio Pictures, Inc., 327 U.S. 251, 264 (1946). Indeed, under the holding of the Bigelow case, supra, it would appear that if the plaintiff has proved that defendant's acts were the cause of his injury he has also satisfactorily proved the amount of his damages. See Clark, The Treble Damage Bonanza: New Doctrines of Damages in Private Antitrust Suits, 52 MICH. L. REV. 363, 374-75 (1954); McConnell, The Treble Damage Action, U. Int. L. ForUm 659, 668 (1950); Note, 64 Harv. L. REv. 317, 318 (1950). 
passed by the legislature but vetoed by the governor would it appear possible to establish defendant's responsibility for the restraint; and although the state of mind of only one man is involved, the task of proof remains a difficult one because of the necessity of relying on circumstantial evidence.

While it may be impossible to prove damage from defendant's conduct, it may still be possible to get an injunction to protect against prospective injury from future repetition of such conduct. ${ }^{70}$ "The mere cessation of an unlawful activity before suit does not deprive the court of jurisdiction to provide against its resumption . . . (unless it apears) that there is no reasonable expectation that the wrong will be repeated." 80 In addition, the court may allow costs if both an injunction and damages were sought but damages were not recovered. ${ }^{81}$

\section{CONCLUSION}

The basic problem presented by application of antitrust sanctions to private conduct seeking to restrain competition through state legislative action results from a conflict between the role of government in regulating individual and group conduct for the general welfare and its role in providing social unity through reconciliation of varied individual and group interests freely expressed under the protection of the first amendment. It is believed that the language of sections 1 and 2 of the Sherman Act is sufficiently broad to encompass lobbying activities and that the problem therefore becomes one of determining the limitations upon congressional power imposed by the principle of federalism and the first amendment. Although doctrinally the language of the Sherman Act permits of no distinction on the basis of motive, it would appear that the principle of federalism requires that those individuals seeking exercises of the states' police power for reasons properly the concern of the states should be held immune from antitrust sanctions. ${ }^{82}$ In the case of those seeking a state enactment for the purpose of restraining trade, the first amendment may provide a shield, at least in those cases in which the lobbyist's activity is not accompanied by other conduct inimical to the interests of society. However, where the inducement of state legislative activity is merely part of a larger conspiracy to restrain trade or where the lobbyist resorts to measures designed to deceive or corrupt the legislature, first amendment protection may be withdrawn thereby exposing the lobbyist to the far

79. Mid-West Theatres Co. v. Co-operative Theatres, Inc., 43 F. Supp. 216, 224 (E.D. Mich. 1941) ; Ring v. Spina, 84 F. Supp. 403, 406 (S.D.N.Y. 1949) ; cf. Georgia v. Pennsylvania R.R., 324 U.S. 439 (1945).

80. United States v. Aluminum Co., 148 F.2d 416, 448 (2d Cir. 1945); United States v. Insurance Bd., 144 F. Supp. 684, 691 (N.D.' Ohio 1956) and cases cited therein.

81. Ring v. Spina, 84 F. Supp. 403, 408 (S.D.N.Y. 1949).

82. The recent decision in Noerr Motor Freight, Inc. v. Eastern Railroad Presidents Conference, Civil No. 14715, E.D. Pa., Oct. 10, 1957, supports this conclusion. In its discussion of the defenses raised to plaintiffs' action, the court states: ". . . it is not a mere legislatively-created monopoly that is under attack in this case. It is a conspiracy to destroy a competitor . . . as well as the fomentation of government restrictions." 
reaching provisions of the Sherman Act. ${ }^{83}$ Although an individual's conduct may have contravened the prohibitions of the Sherman Act, practical evidentiary problems may make difficult the prosecution of a treble damage action. Establishing a causal connection between the defendant's attempts to secure legislation and passage of that legislation poses peculiar problems because of the judicial policy against inquiring into the motives of particular legislators. However, there appears to be no reason why injunctive relief may not be available in appropriate cases.

P. H. O.

83. See Noerr Motor Freight, Inc. v. Eastern Railroad Presidents Conference, supra note 82, where the court concludes: ". . the defendants' conduct is not within that broad expanse of conduct which is protected by the First and Fourteenth Amendments. What the defendants have combined to do is something more than free speech; something more than freedom to assemble; something more than a petition to the legislature." 